\title{
National Dialogue or Election Matters In Ethiopia: Critical Analysis of The Current Political Situation And The $6^{\text {th }}$ National Election
}

\author{
Yitagesu Bekele \\ Department of Governance and Development Studies, Mizan-Tepi University. Ethiopia \\ yitagesubekele@mtu.edu.et
}

\begin{abstract}
In Ethiopia, elections had been conducted at different times. The general election was held for the first time in 1992. Since then, the country has made four consecutive elections; however, almost all elections were accompanied by complains of opposition parties, pre, and post-election conflicts. Nowadays, Ethiopia is a country where divided interests are underway due to ethnic conflict and political uncertainties that happened as the result of the absence of elites' consensus on varieties of unanswered national concerns, identity, and political questions. Surrounded by all the aforementioned problems, the government has held the sixth national election. Even if the election was said orderly, peaceful, and credible by some observers accredited by the National Election Board of Ethiopia, the election was not conducted in many parts of the country due to ethnic conflict. In line with this, the USA and EU said that the election was not democratic and credible because the current political atmosphere of the country wouldn't conducive to conduct election; due to major opposition parties boycotted themselves from the election, influential politicians are imprisoned and ethnic clashes in many parts of the country. Therefore, to sustain the country as a unified state and reach into consensus on national issues the government had better initiate the national dialogue process and make a viable peace agreement with all conflicting parties rather than holding an election.
\end{abstract}

Keywords: Conflict, divided interests, election, national dialogue

\section{Introduction}

Free and fair election play a vital role in political transition by evolving democratization and encouraging political liberalization that helps to promote peaceful and democratic political transformation which leads to the increment of stability and prosperity (Waldemar W., 2013).

In Ethiopia, the first regional and local (Wereda) election was held in 1992. This election was manifested as the first election of the transitional period, which had been held to elect representatives for 14 new regional assemblies. The main political movement competing for power was the EPRDF, the All-Amhara People's Organization, and the Oromo Liberation Front.

However, the first multi-party parliamentary election for the federal and regional parliaments was held in 1995 . One of the major dimness observed in this federal and regional election was that many opposition and independent candidates boycotted the election and that made the election not competitive. The opposition parties that boycotted the election are blaming the undemocratic practices of the ruling party. In the $2^{\text {nd }}$ multi-party national election that was held in 2000, none of the major legal opposition parties shunned the election. For the first time since EPRDF took over power, many opposition parties participated in the election.

On May 2005, Ethiopia held the third multi-party national election; it was believed to be the most credible and modest election the country has experienced ever before. In this election, the EPRDF and its junior allies won the majority vote they won more than $90 \%$ of the seats in the federal parliament: arithmetically the EPRDF won 520 seats from the entire 547 seats federal parliament. Opposition parties succeeded to win only 13 
seats both in the federal and regional parliaments (Kjetile T., 2010). On May 23, 2010, the country conducted its fourth national election. In this election EPRDF won 499 seats out of 547 seats, opposition or independent candidates won 2 seats and the EPRDF allied parties won the remaining seats (ibid).

The past five elections held at different times in Ethiopia have had its role in the democratization process of Ethiopia. However, all elections were accompanied by different sorts of conflicts that were raised pre, during, and post-election periods (Wondwosen Teshome, 2009). As a result of these conflicts, different members of opposition parties boycotted themselves from the election, members of opposition political parties, civil societies, individuals, and journalists were arrested; and many peoples have been killed. Therefore, the purpose of this study is to provide insight to the government to formulate a policy framework to bring persistent peace during and post-election period and initiate allinclusive national dialogue to reach a consensus on national issues.

\section{Method}

This paper is qualitative research based on the need for national dialogue in Ethiopia (the country that is highly divided both politically and ethnically). All information and knowledge can be obtained from secondary sources such as books, articles, reports, and that of online newspapers (Reporter and Addis Zemen) published regarding the current political condition and election of the country. Besides, secondary data is obtained through tracking data through mass media and online social media and then interpreted with a theoretical approach.

\section{Results and Discussion}

\subsection{The Current Political Situation and} the $6^{\text {th }}$ National Election of Ethiopia

Currently, there is no consensus regarding numerous issues ranging from the symbol of the nation (national flag), the national language, ownership of the capital city, constitution of the country, and most prominently the federal structure/ or the system itself (Tsion Belay and Michelle N. et al, 2020). As a result of these, these days, Ethiopia is ethnically divided and flattened with various civil resistance, street blocked and small-scale conflicts, all in all, chaos from every corner of the country. Some of the conflicts are due to the current national political reform introduced by the Prime minister of Abiy Ahmed, as is seen in the case of the Somali regional State and that of Wollega, from Oromia. Others are due to path-dependent questions for equitable economic benefit and in pursuit for state infrastructure and actual state somatic presence, as was the case in Konso from SNNPR. Additionally, there are numerous confrontations meant for state recognition of ethnic identity and in pursuit of apprehending constitutionally enshrined rights for self-rule as the case in Raya and Wolkite from Amhara Regional State. While the remaining dozens of latest questions in Ethiopia and southern Ethiopia, in particular, are related with 'clamor' for Woreda, Zone, and Regional Statehood (Zemelak, 2018). Based on the prevailing official sources Sidama, Guraghe, Kaffa, Gamo, and Benc'Maji zone councils, have unanimously resolved to disaffiliate from SNNPRs and establishes their statehood on one side and each of these Zones beheld various local and localized conflicts with material and human casualties. In this regard, several conflict studies scholars have pointed out the risks that competitive elections bring about in divided societies. Elections in divided societies may become the focal point of tensions and thus bear the risk of violence (Sofie. D. and Wolfgang.W, 2013). The best example in this regard is the election in Kenya, Nigeria, and Niger.

With all the aforementioned political uncertainty of the country and postponing of election repetitively caused by Covid-19 and various technical difficulties, the election was held on June 21, 2021, G.C. According to the national election board of Ethiopia 
more than 37 million of Ethiopian's out of 110 million people were registered to vote over 46 parties and more than 9000 candidates. Even if the USA and European Union have not sent observers teams due to the government of Ethiopia not accepted certain standards set by the USA and European Union by saying the standards that the government urged to fulfill are against its sovereignty (Aly V., June 17, 2021). However, two international observer groups credited by the national election board of Ethiopia observed the election. These are the East Africa Standby Force (EASF) and African Union Election Observer Mission. Both of them in their preliminary reports said that:

"Despite Covid-19 pandemic, security, politics, operational and logistic inconveniences the pre-election and election day processes were conducted in an orderly, peaceful and credible manner"' (Retrieved August 9, from https://au.int/en/pressrelease)

However, the election was declared peaceful and credible, both by the ruling party and accredited observers' groups; this election was not conducted in four regions out of 10 regions in the country. Two regions, Somalia and Harar voting postponed until September as a result of problems with the ballot and ethnic clashes. In the Tigray region, the election date has been unknown due to conflict that vented there between the Ethiopian military and the region's former ruling party the Tigray people's Liberation Front (TPLF). The voting was also not apprehended in some areas of the Benishangul Gumuz Region due to ethnic violence which inept voters registration. Likewise, voting was not conducted on the specified period in different areas for different reasons. For instance, in Addis Ababa, some constitute unities voting was not started on stated time due to election coordinators not arrive on time. Similarly, in the Sidama region, election coordinators delayed voting for one day because less than half of the ballot papers arrived at the polling station. Moreover, in Amhara and South Nation Nationalities and people's Regional competent political parties complained their observatories and agents were beaten and their badges confiscated. In his regard the main competent party leader professor Birhanu Nega said that;

"His Ethiopians for social justice party had filed around 207 complains after local officials and police forces in the region blocked party observers and tensioned voters" (EBC, the main news outlet of the country)

In supporting the above, the head of Ethiopia National Election Board in her televised press release on June 22, 2021, confirmed that the board received more grumbles from different polling stations around the country and canceled some election results in Oromia and South Nation Nationalities, and Peoples' Regional States. This all indicated that whoever won the election all competing parties may not accept the result. Thus, this may additionally threat to the formerly ethnically and politically divided nation.

\subsection{The Need for National Dialogue in Ethiopia}

The national dialogue is a progressively popular tool for conflict resolution and handling political transformation (Mossa, E. and Lau S.etal, 2020). It can widen debate regarding a country's paths beyond the usual elite decision-makers. It is one of the tools used to build harmony among contending political forces to resolve major political differences and avoid violent conflict. The national dialogue has been used as an instrument to resolve the political crisis and pave the way for political transitions and sustainable peace. This approach has been apprehended throughout contemporary history and across the world in $18^{\text {th }} \mathrm{c}$ in America. Likewise, the national dialogue has played a significant role by facilitating political re-organization, transition process, and drafting of the new constitution in Southern, Central, and Eastern Europe in the 
1970s and 1980s (Anne Z.and Thania P. et'al , 2016). Also, in the early 1990s, a national dialogue was a popular format for political processes initiated in several African countries for instance in Kenya, Tunisia, Egypt, Sudan, Morocco....etc (Dawit Yohannes and Meresa Kahsu, 2020). Ethiopia is one of the oldest East African nations that need genuine national dialogue to promote peaceful coexistence among societies. Ethiopia has agonized structural as well as human identity crises for over a century. The varieties of national issues have been in dilemma. Many Ethiopians have surrendered their lives to resolve these problems while not a few choose to remain in denial the institutional building and the democratization process also not succeeded. This is because, the political system of Ethiopia is not a product of political bargain, genuine competition, and a national consensus of an inclusive approach to governance (Jiregna Tadese, 2020).

\section{Conclusion}

As discussed earlier, in Ethiopia currently both scholars and political elites are not agreed on numerous issues ranging from the symbol of the nation (national flag), the national language, ownership of the capital city, constitution of the country, and most prominently the federal structure/ or system itself. As a result, an ample of national and political questions that are still unanswered, societies deeply divide both ethnically and politically, conflicts and war here and there. Within all these circumstances, the government had conducted the $6^{\text {th }}$ national election. Besides, this election was said that orderly, credible, and peaceful by accredited observers. However, United State and European Union said that the election was not credible and democratic because the current political atmosphere of the country is not suitable to conduct an election. Again, some strong opposition political parties boycotted themselves from the election, influential politicians are imprisoned, and ethnic conflicts in many parts of the country remain threatening. Furthermore, in many parts of the country, millions of the population didn't get the chance to elect their representatives as a result of the extension of the election, ethnic conflict, and political uncertainties.

\section{Recommendation}

Different political scientists argue that national dialogue is the most effective way for divided societies to assure their stability and promote durable peace. Therefore, to continue the country as a unified state and reach into consensus on national issues, the government has better initiate an allinclusive national dialogue process and make a viable peace agreement with all conflicting parties rather than holding an election.

\section{References}

Aly, V. (June 17, 2021). Why Ethiopia's 2021 election Matters. USA: United States Institute of Peace.

Belay, T., \& Ndiaye, M. (2020). Ethiopia: Conflict Insights.

Dessu, M. K., \& Yohannes, D. (2020). National dialogues in the Horn of Africa: lessons for Ethiopia's political transition. ISS East Africa Report, 2020(32), 1-24.

Elayah, M., Schulpen, L., van Kempen, L., Almaweri, A., AbuOsba, B., \& Alzandani, B. (2020). National dialogues as an interruption of civil war-the case of Yemen. Peacebuilding, 8(1), 98117.

Kjetile T. (2010). The Ethiopian 2010 federal and regional elections. reestablishing the one-party state. Journal of African affairs.

Sofie. D. and Wolfgang.w. (2013). Designing election in conflict-prone divided societies in the case of South Sudan. Frankfurt, Germany.: Peace and research institute Frankfurt.

Tadese, J. (2020). National Reconciliation and Major National Issues Pathways for Sustainable Peace. Journal of Contemporary African Studies. 
Teshome-Bahiru, W. (2009). Electoral Violence in Africa: Experience from Ethiopia. International Journal of Humanities and Social Sciences, 3(2), 176-201.

Waldemar, W. (2013). Functions of Elections in Democratic Systems. Political Preferences, 4, 2013.

Zachariassen, A., Paffenholz, T., Çuhadar, E., \& Ross, N. (2016). Transforming Intractable Conflicts: Restructuring and Reframing Syracuse University, Syracuse 23-24 September 2016.

Zemelak, A. (2018). Opinion: The Clamor For Own State In Ethiopia: Ill-Timed. retrieved May 5. 